\title{
Determining intention to buy air e-tickets in Malaysia
}

\author{
Kwee-Fah Lee ${ }^{\text {a }}$, Ahasanul Haque ${ }^{a^{*}}$, Suharni Maulan ${ }^{\text {a }}$ and Kalthom Abdullah ${ }^{a}$
}

${ }^{a}$ Universiti Tunku Abdul Rahman, International Islamic University Malaysia, International Islamic University Malaysia

\begin{tabular}{l}
\hline C H R O N I C L E \\
\hline Article history: \\
Received: January 18, 2019 \\
Received in revised format: Feb- \\
ruary 21, 2019 \\
Accepted: February 22, 2019 \\
Available online: \\
February 22, 2019 \\
\hline Keywords: \\
Perceived risk \\
Airline \\
E-tickets \\
Intention \\
Online
\end{tabular}
\section{A B S T R A C T}

\begin{abstract}
Struggling airlines can save cost and improve profits by selling tickets online. While global sales of air e-tickets have grown over time, they are mostly from advanced nations. In developing markets like Malaysia, e-ticket sales are substantially lower. Hence, this study sets out to examine the factors that determine consumers' intentions to buy air e-tickets. The factors include the disadvantage and advantage of buying air e-tickets, represented by perceived risk and perceived usefulness, respectively. The results show that Malaysian consumers' perceptions of risk outweigh the perceived usefulness of e-ticketing, and negatively affect intentions to buy air e-tickets. Perceived risk also has a negative effect on perceived usefulness, making usefulness insignificant to buying intention online. These findings imply that for Malaysian consumers, perceived risk far outweighs perceived usefulness where intention to buy air e-tickets is concerned.
\end{abstract}

C 2019 by the authors; licensee Growing Science, Canada

\section{Introduction}

Airlines typically incur high operational costs, impacting profits negatively. To save the ailing air industry, from 2008, the International Air Transport Association (IATA) requested all its members to adopt eticketing in order to cut costs. E-ticketing allows travellers to book flights directly online thus bypassing physical travel agents and airline ticketing offices. Savings come from eliminating huge commissions paid to agents, and downsizing of costly ticketing offices. Globally, online flight bookings have grown over time, coming mostly from advanced nations such as the United States, United Kingdom and Japan (WNS, 2014). However, in developing nations like Malaysia, many travellers still book air tickets from traditional physical channels. To improve profits, it is important for airline managers to understand the factors that influence Malaysians to buy e-tickets so that more effective strategies may be developed to persuade travellers to book online. Hence, this study sets out to examine the disadvantage and advantage of buying air e-tickets. It aims to answer the following research questions: (1) Do consumers' perceived risk influence their intention to buy air e-tickets? (2) What are the perceived risk dimensions? (3) Does perceived usefulness of the internet affect intention to buy air e-tickets? (4) What is the effect of perceived risk on perceived usefulness of the internet? The paper is structured as follows. First, a review of the literature is presented. Second, the methodology used is described. Third, the results are analysed and the

* Corresponding author.

E-mail address: ahasanul@iium.edu.my (A. Haque) 
findings provided. Lastly, there is a discussion on the study, followed by recommendations for future research.

\section{Literature review}

\subsection{Travellers' behaviours}

For travellers, there are advantages and disadvantages for buying air tickets online rather than offline. Most likely, they will compare the pros and cons of buying from the two different channels. When the cons outweigh the pros of buying online, travellers will choose to buy from physical channels such as travel agencies. Research shows that while most people are aware of the pros such as greater convenience and usually lower prices for e-tickets (Crespo-Almendros \& Del Barrio-García, 2016; Gu et al., 2009), many check out flight information online and then proceed to buy offline in Spain (Ruiz-Mafé et al., 2009). Malaysian travellers seem to behave likewise (Singapore Tourism Board, 2014). To buy air tickets online, a consumer must use self-service technology to surf the internet to check ticket prices, routes, make comparisons, and then key in the correct flight details (Cunningham et al., 2005; Bukhari et al., 2012). The consumer will suffer from any mistakes made as it is often difficult to rectify mistakes especially those involving changes to travel itineraries. Thus, there is a greater perceived risk of buying air tickets online than offline.

\subsection{Perceived risk}

Buying risk is unavoidable since uncertainty surrounds the future outcome of any purchases (Bauer, 1960), which may be bad. Unsurprisingly, consumers perceive the presence of pre-purchase risk. In general, risk is perceived subjectively. According to Cox and Rich (1964), perceived risk is the amount involved in a purchasing decision, and the consumer's subjective feelings of certainty that she will "win" or "lose" all or some of the amount paid. Mitchell (1999) supported this argument by asserting that consumers can never know the exact probability of a purchase outcome. Hence, risk can only be assessed subjectively. Perceived risk can be separated into a few dimensions including financial, privacy, security, performance, and psychological risks. In online shopping, financial risk refers to loss of money (Forsythe $\&$ Shi, 2003). It is the risk of paying more for buying from one seller than another. The absence of faceto-face contact with the seller increases the financial risk of buying online. Studies show there is perceived financial risk for online shopping including air e-tickets (Ueltschy et al., 2004). Privacy risk refers to a consumer's uncertainty about website sellers collecting, using and distributing information about the individual and his/her behaviour to others without the consumer's permission and knowledge beforehand (Featherman et al., 2010; Ha \& Stoel, 2009). Online shopping studies indicate the presence of perceived privacy risk among consumers (Crespo et al., 2009; Ruiz-Mafé et al., 2009). Perceived security risk is the consumer's level of uncertainty and mistrust of revealing private and financial information online (Coker et al., 2011). It has also been described as consumers' perceptions that unknown third parties may hack computer systems to steal their transaction-related, personal, or financial information from credit card details transmitted online to the web seller for payments (Nepomuceno et al., 2012). In booking travel online, consumers perceive that there is a security risk involved (Park et al., 2016). Performance risk has been described as consumers' perceptions that an item under purchase consideration may not meet expectations (Jarvenpaa \& Todd, 1996). For service items, this risk relates to the possibility of a bought service not being carried out satisfactorily (Mitchell, 1992). Ruiz-Mafé et al. (2009) found that performance risk significantly affects travellers' decision to buy air e-tickets. Psychological risk involves disappointment with oneself for making a bad purchase (Cases, 2002). Consumers often mention psychological risk as their reason for not shopping online (Forsythe \& Shi, 2003). For air tickets, Ruiz-Mafé et al. (2009) revealed this risk as the main concern of consumers who fear losing self-esteem for buying the wrong ticket online, and suffering stress and anxiety as a result. 


\subsection{Perceived risk buying intention}

Risk is generally perceived during the early stages of the five steps purchase decision process (Kotler \& Armstrong, 2016). This is supported by studies on air e-ticket bookings (Cunningham et al., 2004; Cunningham et al., 2005). Buying risk is perceived as soon as the customer recognizes the need for a product, and tends to remain until the time of actual purchase. Since risks are perceived before buying, they affect the consumer's intention to proceed or stop the purchase. Such behaviour has been observed in past studies on online as well as offline shopping. For the former, the items examined included travel shopping (Amaro \& Duarte, 2013), air tickets (Cunningham et al., 2005), electronic items (Coker et al., 2011), and general shopping (Samadi \& Yaghoob-Nejadi, 2009). Overall, these studies demonstrate that consumers' risk perceptions exert a direct negative effect on intention to buy online. Therefore, it is hypothesized that:

$\mathrm{H}_{1}$ : Perceived risk has a negative relationship with buying intention for air e-tickets.

\subsection{Perceived usefulness and buying intention}

Buying air tickets online can also be beneficial to consumers. Past studies indicate that perceived usefulness of the internet can influence consumers' intentions to book air e-tickets in Malaysia (Mohd Suki \& Mohd Suki, 2017). According to the Technology Acceptance Model (Davis, 1986), perceived usefulness influences people's acceptance or rejection of information technology. Davis (1989) described perceived usefulness (PU) as the degree of an individual's belief that using a particular system would improve one's job performance. To date, most information systems (IS) studies found significant relationships between PU and intention. In a meta-analysis, Yayla and $\mathrm{Hu}$ (2007) investigated user intentions based on a compilation of 32 IS studies and found PU to be an important factor that influences intentions.

In online consumer studies, similar results have been observed for shoppers who used websites for general shopping (Akhlaq \& Ahmed, 2014; Li \& Huang, 2009), banking (Alalwan et al., 2016), buying travel products (Kucukusta et al., 2015), and air tickets purchasing (Mohd Suki \& Mohd Suki, 2017). Overall, various products and service offerings in commercial websites enable consumers to make better purchase decisions. Thus, it can be expected that many consumers would perceive the internet useful for shopping purposes, leading to an increased intention to buy online. Therefore, it is suggested that:

$\mathrm{H}_{2}$ : There is a positive relationship between perceived usefulness and buying intention for air e-tickets.

\subsection{Perceived risk and perceived usefulness}

Studies investigating the relationship between perceived risk and PU have found mixed results. For example, Chan and Lu (2004) performed an investigation on internet banking and detected that risk perceptions negatively affect PU for potential adopters but there is no effect for current users. Other studies found perceived risk and PU to be unrelated. Faqih (2013) found a non-significant relationship between consumers' perceptions of risk and usefulness of the internet for online shopping. Similarly, Featherman and Pavlou (2003) found that perceived risk and PU had no significant relationship with each other. In contrast, Featherman and Wells (2010) found that risk perceptions significantly reduce PU of paying bills online. Likewise, Li and Huang's (2009) findings revealed that perceived risk had a negative influence on the internet's PU for online shopping. Another study on online travel shopping also showed that the higher the perceived risk, the less the website is perceived as useful for purchasing (Kamarulzaman, 2007). Thus, it is proposed that:

$\mathrm{H}_{3}$ : There is a negative relationship between consumers' perceived risk and perceived usefulness of the internet. 


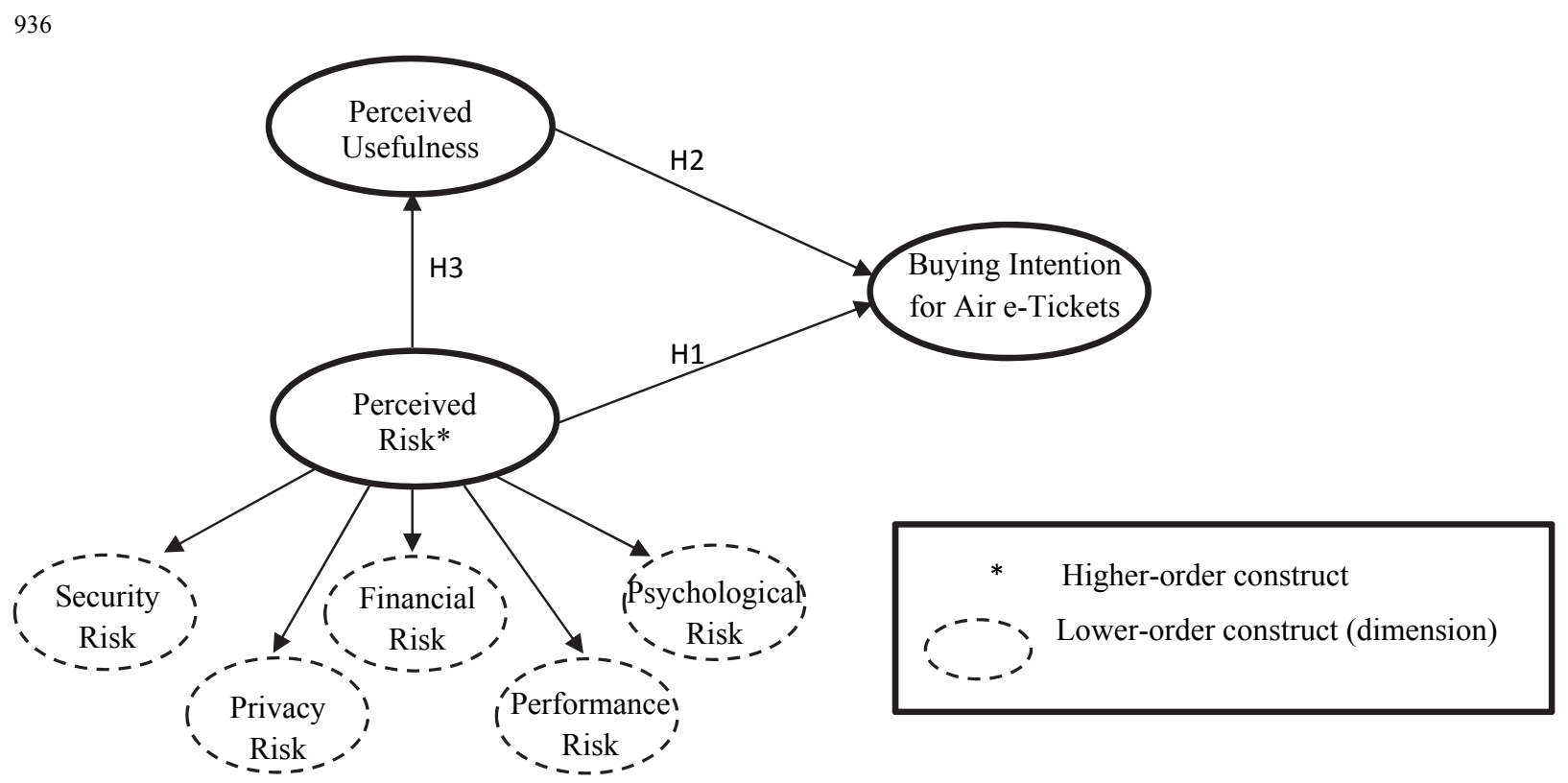

Fig. 1. The Research Framework

\section{Methodology}

Data was collected online using a survey questionnaire developed in English and based on questions adapted from several past studies (i.e. Featherman \& Pavlou, 2003; Kim et al., 2005; Ruiz-Mafé et al., 2009). The questionnaire had two sections. First, demographic data was requested. Second, survey questions were posed with the response to each question anchored on a seven-point Likert scale from (1) strongly disagree to (7) strongly agree. A pre-test test was conducted before actual data collection. Based on the feedback, some wordings were amended to improve the clarity of the questions. Thereafter, the questions were inserted into Google Docs. This was followed by invitations to potential Malaysian respondents which included a link to participate in the online survey, via emails and the social media networks of WhatsApp as well as Facebook (Alavi et al., 2019; Tayebi et al., 2019; Gilani et al., 2019; Pourkhani et al., 2019). At the end of the survey period, a total of 304 replies were received. After the data was screened, 231 responses remained.

\section{Results}

\subsection{Descriptive analysis}

The profile of the respondents is shown in Table 1. Out of 231 responses, $29.9 \%$ and $64.1 \%$ were males and females, respectively. Most respondents were between 30 and 39 years old (33.3\%), followed by the 18 to 29 age group (24.7\%). Both the 40 to 49 , and 50 to 59 age groups made up $15.6 \%$ each. This is followed lastly by the 60 and above age group with $10.8 \%$ of the total respondents. Majority received a tertiary education $(83 \%)$ with the rest having completed secondary or vocational school only. For marital status, most were married (55.4\%) while $41.1 \%$ were single, $2.2 \%$ divorced and $0.9 \%$ widowed. In terms of income, the majority of the respondents earned RM3,000 to RM6,999 per month with quite similar distribution between the RM3,000 to RM4,999 (24.2\%) and RM5,000 to RM6,999 (20.3\%) groups. Next, $18.6 \%$ of the respondents made less than RM1,000 per month followed by the RM1,000 to RM2,999 $(13.4 \%)$ and RM7,000 to RM9,999 (13.0\%) groups. The least number of respondents came from the highest income group which earned RM10,000 and above (8.2\%). 
Table 1

The Respondents' Profile

\begin{tabular}{|c|c|c|}
\hline & Frequency & Percent \\
\hline \multicolumn{3}{|l|}{ Gender $(n=231)$} \\
\hline Male & 69 & 29.9 \\
\hline Female & 148 & 64.1 \\
\hline Missing & 14 & 6.1 \\
\hline \multicolumn{3}{|l|}{ Age } \\
\hline $18-29$ & 57 & 24.7 \\
\hline $30-39$ & 77 & 33.3 \\
\hline $40-49$ & 36 & 15.6 \\
\hline $50-59$ & 36 & 15.6 \\
\hline 60 and above & 25 & 10.8 \\
\hline \multicolumn{3}{|c|}{ Highest level of educational attainment } \\
\hline Secondary/vocational school & 38 & 16.4 \\
\hline Diploma & 25 & 10.8 \\
\hline Bachelor degree & 53 & 22.9 \\
\hline Post-graduate & 92 & 39.8 \\
\hline Professional degree & 22 & 9.5 \\
\hline \multicolumn{3}{|l|}{ Marital status } \\
\hline Single & 95 & 41.1 \\
\hline Married & 128 & 55.4 \\
\hline Divorced & 5 & 2.2 \\
\hline Widowed & 2 & 0.9 \\
\hline \multicolumn{3}{|l|}{ Monthly income } \\
\hline Below RM1,000 & 43 & 18.6 \\
\hline RM1,000 - 2,999 & 31 & 13.4 \\
\hline RM3,000 - 4,999 & 56 & 24.2 \\
\hline RM5,000 - 6,999 & 47 & 20.3 \\
\hline RM7,000 - 9,999 & 30 & 13.0 \\
\hline RM10,000 and above & 19 & 8.2 \\
\hline
\end{tabular}

\subsection{Data analysis}

While descriptive data was analysed using SPSS version 20, SmartPLS 2.0.M3 (Ringle et al., 2005) was used to validate the measurements and test the hypotheses. PLS-SEM is a vigorous technique that enables complex higher-order models to be measured. In this study, Perceived Risk was conceptualized as a higher-order reflective-reflective construct (Jarvis et al., 2003). The two-step procedure was followed to evaluate the research model (Chin, 2010). First, the measurement model was evaluated for reliability, followed by convergent and discriminant validity. Second, the structural model was examined for the strength and direction of the path relationship.

\subsubsection{Measurement Model Evaluation}

As shown in Table 2, composite reliabilities range from 0.889 to 0.956 whereas Cronbach's alpha were between 0.809 and 0.909 . All values are well above the minimum threshold of 0.70 , indicating high internal consistency reliability within each construct (Nunnally, 1978). The model was also tested for convergent and discriminant validity. Convergent validity was measured using the average variance extracted (AVE). The acceptable lower threshold is 0.50 (Fornell \& Larcker, 1981). From Table 2, all AVE scores are above 0.50 supporting convergent validity of the indicators for each construct. To confirm discriminant validity, the data was first screened for cross loadings. To improve the model quality, the number of indicators was reduced from 24 to 19 . Next, the AVE square root of a construct must be higher than its correlation with other constructs (Fornell \& Larcker, 1981). In Table 3, the off-diagonal values are lower than the AVE square root along the diagonal, thus establishing adequate discriminant validity between each construct in the model. 
Table 2

Construct Reliability and Convergent Validity

\begin{tabular}{|c|c|c|c|c|c|c|}
\hline Construct/Indicators & Item & $\begin{array}{l}\text { Outer } \\
\text { loading }\end{array}$ & t-value & $\begin{array}{l}\text { Composite } \\
\text { reliability }\end{array}$ & $\begin{array}{l}\text { Average } \\
\text { variance } \\
\text { extracted }\end{array}$ & $\begin{array}{l}\text { Cronbach's } \\
\text { alpha }\end{array}$ \\
\hline $\begin{array}{l}\text { If I use the internet to buy air tickets: } \\
\text { Security Risk (SR) }\end{array}$ & & & & 0.932 & 0.821 & 0.891 \\
\hline $\begin{array}{l}\text { - it would be insecure to send sensitive in- } \\
\text { formation over the internet }\end{array}$ & $\mathrm{S} 1$ & 0.895 & 47.047 & & & \\
\hline $\begin{array}{l}\text { - my credit card details are likely to be sto- } \\
\text { len }\end{array}$ & S2 & 0.916 & 71.077 & & & \\
\hline $\begin{array}{l}\text { my personal details could be accessed by } \\
\text { an unknown third-party }\end{array}$ & S3 & 0.907 & 60.153 & & & \\
\hline Privacy Risk (PRR) & & & & 0.889 & 0.728 & 0.809 \\
\hline $\begin{array}{l}\text { - my personal details could be used without } \\
\text { my consent }\end{array}$ & PR1 & 0.900 & 46.530 & & & \\
\hline $\begin{array}{l}\text { - my personal details could be used without } \\
\text { my knowledge }\end{array}$ & PR2 & 0.891 & 50.525 & & & \\
\hline - I would receive a lot of spam in the future & PR3 & 0.762 & 23.028 & & & \\
\hline Financial Risk (FR) & & & & 0.909 & 0.770 & 0.850 \\
\hline $\begin{array}{l}\text { - I would not get my money's worth from } \\
\text { the tickets }\end{array}$ & F1 & 0.907 & 70.429 & & & \\
\hline - it would lead to a financial loss to me & F2 & 0.882 & 46.249 & & & \\
\hline $\begin{array}{l}\text { - it would be unwise as I can get a better } \\
\text { deal elsewhere }\end{array}$ & F3 & 0.841 & 32.624 & & & \\
\hline Performance Risk (PER) & & & & 0.913 & 0.778 & 0.857 \\
\hline $\begin{array}{l}\text { it would be difficult to find out about the } \\
\text { flight characteristics (time schedule, } \\
\text { routes, etc.) }\end{array}$ & PE2 & 0.846 & 27.135 & & & \\
\hline $\begin{array}{l}\text { - I am not confident about the ability of the } \\
\text { online seller to perform as expected }\end{array}$ & PE3 & 0.898 & 54.057 & & & \\
\hline $\begin{array}{l}\text { considering the possible problems associ- } \\
\text { ated with the online seller's performance, } \\
\text { there is a lot of risk involved }\end{array}$ & PE4 & 0.901 & 70.063 & & & \\
\hline Psychological Risk (PSR) & & & & 0.911 & 0.774 & 0.854 \\
\hline - I would feel anxious & PS2 & 0.914 & 54.246 & & & \\
\hline - I would feel unnecessary stress & PS3 & 0.897 & 43.195 & & & \\
\hline $\begin{array}{l}\text { - I would feel it does not match my self- } \\
\text { image }\end{array}$ & PS4 & 0.825 & 25.285 & & & \\
\hline $\begin{array}{l}\text { Perceived Usefulness (PU) } \\
\text { Using the internet to buy air tickets: }\end{array}$ & & & & 0.932 & 0.821 & 0.891 \\
\hline - Helps me purchase more quickly & PU2 & 0.884 & 29.403 & & & \\
\hline - Is useful for my air ticket purchases & PU3 & 0.937 & 64.569 & & & \\
\hline - Helps me shop more efficiently & PU4 & 0.894 & 34.396 & & & \\
\hline Buying Intention (BI) & & & & 0.956 & 0.916 & 0.909 \\
\hline $\begin{array}{l}\text { - I will probably use the internet to buy air } \\
\text { tickets in the future }\end{array}$ & BI1 & 0.955 & 131.02 & & & \\
\hline
\end{tabular}

\section{Evaluation of the Higher Order Model}

The repeated indicators approach was used to assign all indicators of the lower-order constructs (LOCs) to the higher-order construct (HOC)(Hair et al., 2014). Convergent validity was assessed for the HOC, Perceived Risk. In Table 4, four outer loading values are slightly below 0.70 , and significant at $\mathrm{p}<0.001$. Hence, they are retained for further analysis. The relationship of the HOC, Perceived Risk, and its LOCs were also assessed. The results in Table 5 show all outer loadings are over 0.70 , and significant at $\mathrm{p}<0.001$. Thus, this confirms convergent validity between Perceived Risk and its LOCs. Then, discriminant validity between Perceived Risk and other model constructs was evaluated using the Fornell-Larcker 
(1981) guideline. From Table 6, the AVE square roots on the diagonal are higher that the off-diagonal values indicating adequate discriminant validity between each construct.

Table 3

Discriminant Validity of the Constructs

\begin{tabular}{lccccccc}
\hline & BI & FR & PER & PRR & PSR & SR & PU \\
\hline BI & 0.957 & & & & & & \\
FR & -0.501 & 0.877 & & & & & \\
PER & -0.570 & 0.766 & 0.882 & & & & \\
PRR & -0.404 & 0.577 & 0.560 & 0.853 & & & \\
PSR & -0.569 & 0.680 & 0.772 & 0.515 & 0.880 & 0.906 & \\
SR & -0.451 & 0.670 & 0.646 & 0.661 & 0.574 & -0.220 & 0.905 \\
PU & 0.203 & -0.233 & -0.205 & -0.258 & -0.280 & - \\
\hline
\end{tabular}

\section{Table 4}

Convergent Validity between the Higher-Order Construct and its Indicators

\begin{tabular}{lccc}
\hline Construct/Indicators & Outer loading & t-value & Average variance extracted (AVE) \\
\hline Perceived Risk (PR) & & & \\
S1 & 0.741 & 19.145 & \\
S2 & 0.777 & 25.781 & \\
S3 & 0.766 & 26.815 & 0.553 \\
PR1 & 0.630 & 12.919 & \\
PR2 & 0.649 & 14.639 & \\
PR3 & 0.672 & 16.684 & \\
F1 & 0.803 & 31.754 & \\
F2 & 0.784 & 26.913 & \\
F3 & 0.724 & 19.563 & \\
PE2 & 0.749 & 21.141 & \\
PE3 & 0.781 & 29.002 & \\
PE4 & 0.832 & 40.424 & \\
PS2 & 0.794 & 27.322 & \\
PS3 & 0.767 & 23.000 & \\
PS4 & 0.655 & 12.628 & \\
\hline
\end{tabular}

Table 5

The Relationship between the Higher-Order Construct and Lower-Order Constructs

\begin{tabular}{llcc}
\hline Higher-Order Construct & Lower-Order Construct & Outer Loading & t-value \\
\hline Perceived Risk & Security Risk & 0.841 & 34.537 \\
& Privacy Risk & 0.768 & 23.259 \\
& Financial Risk & 0.879 & 46.537 \\
& Performance Risk & 0.894 & 59.372 \\
& Psychological Risk & 0.843 & 32.073 \\
\hline
\end{tabular}

\section{Table 6}

Discriminant Validity between the Perceived Risk and Other Model Constructs

\begin{tabular}{lccc}
\hline Construct & PR & PU & BI \\
\hline Perceived Risk (PR) & 0.744 & & \\
Perceived Usefulness (PU) & -0.281 & 0.905 & 0.957 \\
Online Buying Intention (BI) & -0.553 & 0.203 & \\
\hline
\end{tabular}

\subsubsection{Structural Model Evaluation}

Several criteria were evaluated i.e. collinearity issues, model relationships, and predictive relevance. The variance inflation factor (VIF) is used to check for collinearity between constructs in the structural model. In this model, the inner VIF between PR and BI, PR and PU, as well as PU and BI are 1.195, 1.094, and 2.825 , respectively. As the values are far below the threshold of 5 , there are no major problems with 
collinearity. The model relationship is evaluated from the path model. In Fig. 2, the path coefficient from $\mathrm{PR}$ to $\mathrm{BI}$ is -0.538 while $\mathrm{PR}$ to $\mathrm{PU}$ is -0.281 , and both significant at $\mathrm{p}<0.001$. However, the path coefficient of 0.052 for $\mathrm{PU}$ to $\mathrm{BI}$ is insignificant. These results provide support for $\mathrm{H}_{1}$ and $\mathrm{H}_{3}$ while $\mathrm{H}_{2}$ is unsupported. As for predictive relevance, the coefficient of determination, $\mathrm{R}^{2}$, is examined. From Fig. 2 , the $\mathrm{R}^{2}$ for the endogenous construct, $\mathrm{BI}$, is 0.308 . Although higher $\mathrm{R}^{2}$ generally indicates higher level of accuracy, the acceptable value depends on the research discipline. For consumer behaviour studies, $\mathrm{R}^{2}$ of 0.20 are considered high (Hair et al., 2014). As the current research falls under this discipline, it can be interpreted that the model explains a high amount of variance in BI, the endogenous construct. Another predictive relevance criteria is the $\mathrm{Q}^{2}$ value (Geisser, 1974; Stone, 1974). Using the blindfolding procedure (Ringle et al., 2005), the $\mathrm{Q}^{2}$ values for PU and BI were computed and found to be greater than 0 , suggesting that the study model has predictive relevance for the endogenous construct, BI (Hair et al., 2014).

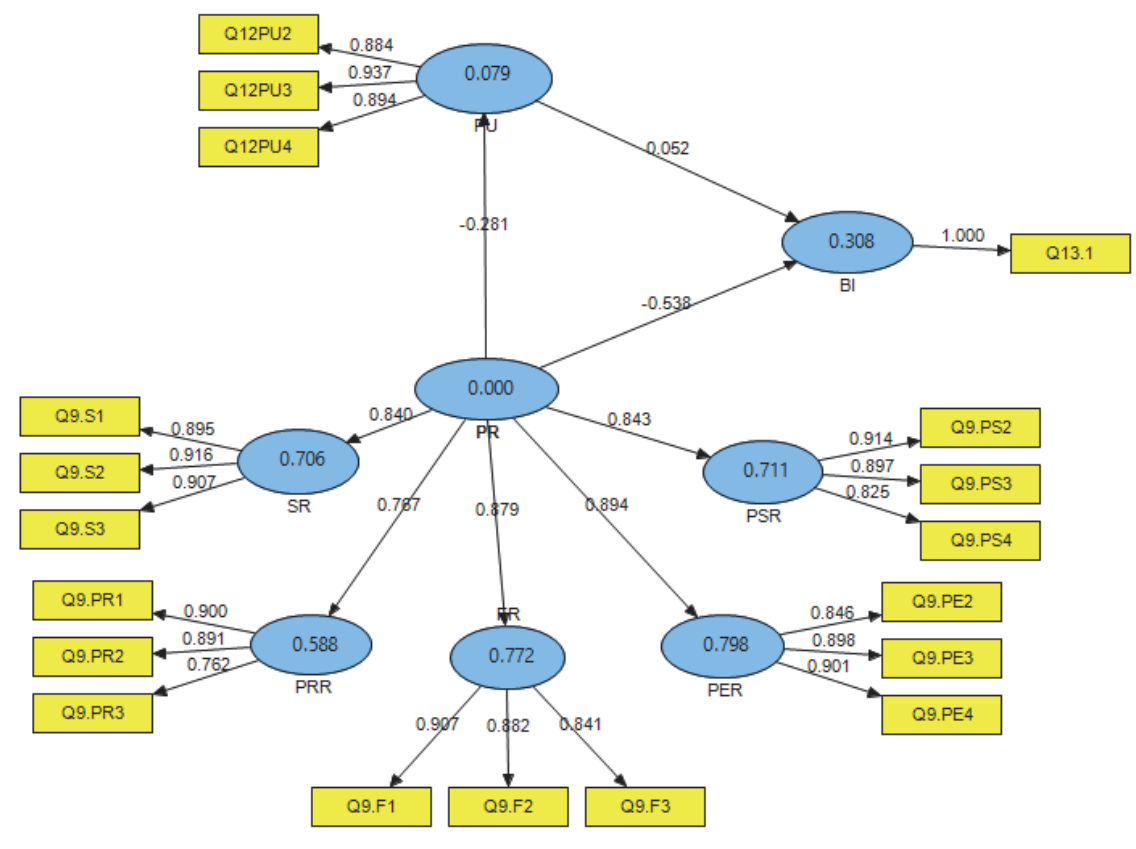

Fig. 2. The PLS-SEM Test Results

\section{Discussion and implication}

Overall, the results provide support for the research model, which is capable of explaining a significant amount of variation in intention to buy air e-tickets. The findings support the perceived risk theory. Risk perceptions affect intentions negatively. The results also demonstrate perceived risk associated with buying air e-tickets as a higher order, multidimensional variable with significant paths to the individual dimensions of security risk, privacy risk, financial risk, performance risk and psychological risk. Together with statistics (Table 3) showing discriminant validity between each risk dimension, the results imply that consumers consider all five risk dimensions in evaluating perceived risk, and that each dimension is viewed as a different aspect of online buying risk. Thus far, research on multidimensional perceived risk relating to air e-ticket bookings has been rather limited. Kim et al. (2005) identified six dimensions of perceived risk as social, time, financial, performance, psychological and security risks among U.S travellers, but they did not link the individual risk dimensions to an overall measure of perceived risk. A later study by the same researchers showed that perceived overall risk comprised of performance, security, financial, physical, psychological and time risks (Kim et al., 2009). However, the second study did not include buying intention of air tickets online. As opposed to the studies by Kim et al. $(2005,2009)$, the current research investigated overall perceived risk, and linking it to online buying intention. Thus, this 
study helps to widen the understanding of perceived risk by testing the theory under air e-ticket settings. The other result of the study shows an insignificant relationship between perceived usefulness and buying intention for air e-tickets, which contradicts other online shopping studies (e.g. Kucukusta et al., 2015; Mohd Suki \& Mohd Suki, 2017). Given the cost and benefit of buying air tickets online, the results imply that consumers put much more weightage on the disadvantages in deciding the purchase medium. This finding corroborates Mitchell's (1999) argument that consumers are more inclined to avoid mistakes than trying to maximize utility in purchasing decisions. Another study result shows that perceived risk is negatively associated with perceived usefulness of the internet. This result is similar to those found in several past studies (e.g. Kamarulzaman, 2007; Li \& Huang, 2009). In the presence of higher perceived risk, Malaysian consumers view air e-ticket booking as less useful. Hence, unsurprisingly perceived usefulness was found to exert no significant effect on intention to buy air e-tickets. From a practical perspective, the study findings suggest that airlines should pay much more attention to consumers' perceptions of risk than usefulness of online booking. Moreover, each risk dimension should be carefully managed so that overall perceived risk will fall below the consumers' threshold limit. When lesser risk is perceived, etickets will also be perceived as more useful. Undertaking such management strategies will be a step in the right direction towards increasing consumers' intention to buy air tickets online, and help improve the bottom line for airline companies.

\section{Limitations and recommendations for future research}

This study has several limitations. Caution must be exercised about the generalizability of the findings since convenience sampling was employed for data collection. This is due to the unavailability of a full list of internet users in Malaysia. Nevertheless, it is a useful indication of Malaysian consumers' behavioural intention of buying air e-tickets. Future research could investigate the model for its applicability in other developing countries. Perhaps a comparison could be drawn between risk perceptions held by consumers from different emerging countries and cultures to enrich knowledge in this area. Another limitation may be due to the nature of the self-administered survey of this study which could have led to some amount of bias. It is possible that the respondents may have given false, socially desired answers. Some people may want to project an image of being technologically clever. A few authors have noted that this issue affects all types of research in the social and marketing area which commonly utilize selfreport surveys (Steenkamp et al., 2010). However, as the survey was done online and likely in private, there is no real pressure to provide false answers to look good to others. Future studies could also apply the research model to other products and services. It would be interesting to see how the model works for these other items as well.

\section{References}

Akhlaq, A., \& Ahmed, E. (2014). Online shopping: A global perspective. Journal of Basic and Applied Scientific Research, 4(5), 153-160.

Alalwan, A., Dwivedi, Y., Rana, N., \& Williams, M. (2016). Consumer adoption of mobile banking in Jordan Examining the role of usefulness, ease of use, perceived risk and self-efficacy. Journal of Enterprise Information Management, 29(5), 118-139.

Alavi, S., Mehdinezhad, I \& Kahshidinia, B. (2019). A trend study on the impact of social media on advertisement.International Journal of Data and Network Science, 3(3), 185-200.

Amaro, S. F., \& Duarte, P. (2013). Factors that influence the purchase of travel online : A proposed model. In M. Kozak \& N. Kozak (Eds.), Aspects of Tourist Behavior (pp. 63-76). Newcastle upon Tyne: Cambridge Scholars Publishing.

Bauer, R. A. (1960). Consumer behavior as risk taking. In R. S. Hancock (Ed.), Dynamic marketing for a changing world: Proceedings of the 43rd National Conference of the American Marketing Association (pp. 389-398). Chicago: American Marketing Association.

Bukhari, S., Ghoneim, A., \& Dennis, C. (2012). Understanding the factors that attract travellers to buy airline tickets online in Saudi Arabia. In European, Mediterranean \& Middle East Conference on 
Information Systems $2012 \quad$ (pp. 619-628). Retrieved from http://www.iseing.org/emcis/emcis2012/EMCISWebsite/proceedings/126.pdf

Cases, A.-S. (2002). Perceived risk and risk-reduction strategies in internet shopping. The International Review of Retail, Distribution and Consumer Research, 12(4), 375-394.

Chan, S., \& Lu, M. (2004). Understanding internet banking adoption and use behavior: A Hong Kong perspective. Journal of Global Information Management, 12(3), 21-43. Retrieved from http://gateway.library.qut.edu.au/login?url=http://search.proquest.com/docview/ 195151617 ?accountid $=13380$

Chin, W. W. (2010). How to write up and report PLS analyses. In V. Esposio Vinzi, W. W. Chin, J. Henseler, \& H. Wang (Eds.), Handbook of Partial Least Squares (pp. 655-690). Berlin: SpringerVerlag.

Coker, B. L. S., Ashill, N. J., \& Hope, B. (2011). Measuring internet product purchase risk. European Journal of Marketing, 45(7/8), 1130-1151.2

Cox, D. F., \& Rich, S. U. (1964). Perceived risk and consumer decision-making: The case of telephone shopping. Journal of Marketing Research, 1(4), 32-39.

Crespo-Almendros, E., \& Del Barrio-García, S. (2016). Online airline ticket purchasing: Influence of online sales promotion type and internet experience. Journal of Air Transport Management, 53, 2334.

Crespo, Á. H., del Bosque, I. R., \& de los Salmones Sánchez, M. M. G. (2009). The influence of perceived risk on internet shopping behavior: A multidimensional perspective. Journal of Risk Research, 12(2), 259-277.

Cunningham, L. F., Gerlach, J. H., Harper, M. D., \& Young, C. E. (2005). Perceived risk and the consumer buying process: Internet airline reservations. International Journal of Service Industry Management, 16(4), 357-372.

Cunningham, L. F., Gerlach, J., \& Harper, M. D. (2004). Assessing perceived risk of consumers in internet airline reservations services. Journal of Air Transportation, 9(1), 21-35.

Davis, F. D. (1986). A technology acceptance model for empirically testing new end-user information systems: Theory and results.

Davis, F. D. (1989). Perceived ease of use, and user acceptance of information technology. MIS Quarterly, 13(3), 319-340.

Faqih, K. M. S. (2013). Exploring the influence of perceived risk and internet self-efficacy on consumer online shopping intentions : Perspective of technology acceptance model. International Management Review, 9(1), 67-78.

Featherman, M. S., Miyazaki, A. D., \& Sprott, D. E. (2010). Reducing online privacy risk to facilitate eservice adoption: The influence of perceived ease of use and corporate credibility. Journal of Services Marketing, 24(3), 219-229.

Featherman, M. S., \& Pavlou, P. A. (2003). Predicting e-services adoption: A perceived risk facets perspective. International Journal of Human Computer Studies, 59(4), 451-474.

Featherman, M. S., \& Wells, J. D. (2010). The intangibility of e-services: Effects on perceived risk and acceptance. ACM SIGMIS Database, 41(2), 110-131.

Fornell, C., \& Larcker, D. F. (1981). Evaluating structural equation models with unobservable variables and measurement error. Journal of Marketing Research, 18(1), 39.

Forsythe, S. M., \& Shi, B. (2003). Consumer patronage and risk perceptions in internet shopping. Journal of Business Research, 56(11), 867-875.

Geisser, S. (1974). A predictive approach to the random effect model. Biometrika Trust, 61(1), 101-107.

Gilani, E., Salimi, D., Jouyandeh, M., Tavasoli, K \& Wong, W. (2019). A trend study on the impact of social media in decision making. International Journal of Data and Network Science, 3(3), 201-222.

Gu, J.-C., Lee, S.-C., \& Suh, Y.-H. (2009). Determinants of behavioral intention to mobile banking. Expert Systems with Applications, 36(9), 11605-11616.

Ha, S., \& Stoel, L. (2009). Consumer e-shopping acceptance: Antecedents in a technology acceptance model. Journal of Business Research, 62(5), 565-571.

Hair, J. F., Hult, G. T. M., Ringle, C. M., \& Sarstedt, M. (2014). A primer on partial least squares 
structural equation modeling (PLS-SEM). Thousand Oaks, CA: Sage Publications Inc.

Jarvenpaa, S. L., \& Todd, P. a. (1996). Consumer reactions to electronic shopping on the world wide web. International Journal of Electronic Commerce, 1(2), 59-88.

Jarvis, C. B., Mackenzie, S. B., \& Podsakoff, P. M. (2003). A critical review of construct indicators and measurement model misspecification in marketing and consumer research. Journal of Consumer Research, 30(September 2003), 199-218.

Kamarulzaman, Y. (2007). Adoption of travel e-shopping in the UK. International Journal of Retail \& Distribution Management, 35(August), 703-719.

Kim, L. H., Kim, D. J., \& Leong, J. K. (2005). The effect of perceived risk on purchase intention in purchasing airline tickets online. Journal of Hospitality \& Leisure Marketing, 13(2), 33-53.

Kim, L. H., Qu, H., \& Kim, D. J. (2009). A study of perceived risk and risk reduction of purchasing airtickets online. Journal of Travel \& Tourism Marketing, 26(3), 203-224.

Kotler, P., \& Armstrong, G. (2016). Principles of Marketing, Global Edition (16th ed.). Harlow: Pearson Education Limited.

Kucukusta, D., Law, R., Besbes, A., \& Legoherel, P. (2015). Re-examining perceived usefulness and ease of use in online booking: The case of Hong Kong online users. International Journal of Contemporary Hospitality Management, 27(2), 185-189.

Li, Y., \& Huang, J. (2009). Applying theory of perceived risk and technology acceptance model in the online shopping channel. World Academy of Science, Engineering and Technology, 53, 919-925.

Mitchell, V. W. (1992). Understanding consumers' behaviour: Can perceived risk theory help? Management Decision, 30(3), 26-31.

Mitchell, V. W. (1999). Consumer perceived risk: Conceptualisations and models. EuroMed Journal of Business, 33(1/2), 163-195.

Mohd Suki, N., \& Mohd Suki, N. (2017). Flight ticket booking app on mobile devices: Examining the determinants of individual intention to use. Journal of Air Transport Management, 62, 146-154.

Nepomuceno, M. V., Laroche, M., Richard, M. O., \& Eggert, A. (2012). Relationship between intangibility and perceived risk: moderating effect of privacy, system security and general security concerns. Journal of Consumer Marketing, 29(3), 176-189.

Nunnally, J. L. (1978). Psychometric theory (2nd ed.). New York: McGraw-Hill.

Park, S., Tussyadiah, I. P., \& Zhang, Y. (2016). Assessment of perceived risk in mobile travel booking. In A. Inversini \& R. Schegg (Eds.), Information and Communication Technologies in Tourism (pp. 467-480). Springer.

Pourkhani, A., Abdipour, K., Baher, B \& Moslehpour, M. (2019). The impact of social media in business growth and performance: A scientometrics analysis.International Journal of Data and Network Science, 3(3), 223-244.

Ringle, C. M., Wende, S., \& Will, A. (2005). SmartPLS 2.0.M3. Hamburg: SmarttPLS. Retrieved from http://www.smartpls.de

Ruiz-Mafé, C., Sanz-Blas, S., \& Aldás-Manzano, J. (2009). Drivers and barriers to online airline ticket purchasing. Journal of Air Transport Management, 15(6), 294-298.

Samadi, M., \& Yaghoob-Nejadi, A. (2009). A survey of the effect of consumers' perceived risk on purchase intention in e-shopping. Business Intelligence Journal, 2(2), 261-275.

Singapore Tourism Board. (2014). STB market insights - Malaysia. Singapore. Retrieved from www.stb.gov.my

Steenkamp, J.-B. E. ., de Jong, M. G., \& Baumgartner, H. (2010). Socially desirable response tendencies in survey research. Journal of Marketing Research, 47(2), 199-214.

Stone, M. (1974). Cross-validatory choice and assessment of statistical predictions. Journal of the Royal Statistical Society, 36(2), 111-147.

Tayebi, S., Manesh, S., Khalili, M \& Sadi-Nezhad, S. (2019). The role of information systems in communication through social media.International Journal of Data and Network Science, 3(3), 245268.

Ueltschy, L. C., Krampf, R. F., \& Yannopoulos, P. (2004). A cross-national study of perceived consumer risk towards online (internet) purchasing. Multinational Business Review, 12(2), 59-82. 
WNS. (2014). Travel and leisure services outsourcing. Retrieved October 22, 2014, from http://www.wns.com/Resources/Articles/Article-Details/104/5-Trends-for-the-Global-AirlineIndustry.aspx

Yayla, A., \& Hu, Q. (2007). User acceptance of e-commerce technology: A meta-analytic comparison of competing models. In ECIS. Paper 5 (pp. 179-190). St.Gallen, Switzerland. Retrieved from http://aisel.aisnet.org/ecis2007/5/

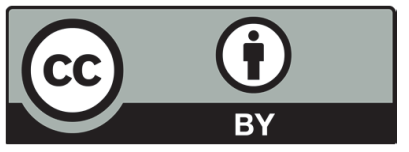

C 2019 by the authors; licensee Growing Science, Canada. This is an open access article distributed under the terms and conditions of the Creative Commons Attribution (CCBY) license (http://creativecommons.org/licenses/by/4.0/). 